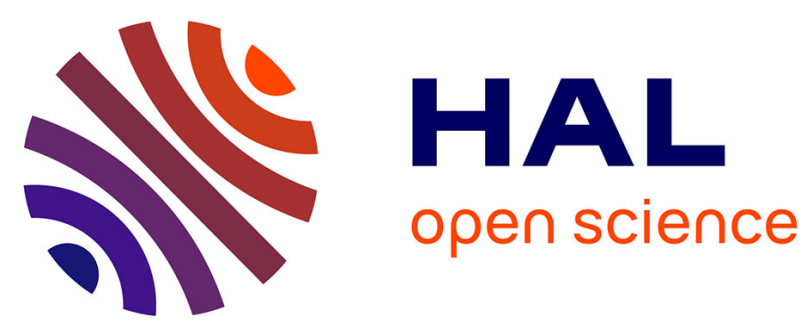

\title{
Co-circulation of bluetongue and epizootic haemorrhagic disease virusesin cattle in Reunion Island
}

Corinne Sailleau, Gina Zanella, Emmanuel Bréard, Cyril Viarouge, Alexandra

Desprat, Damien Vitour, Micheline Adam, Laurent Lasne, André

Martrenchar, Labib Bakkali, et al.

\section{To cite this version:}

Corinne Sailleau, Gina Zanella, Emmanuel Bréard, Cyril Viarouge, Alexandra Desprat, et al.. Cocirculation of bluetongue and epizootic haemorrhagic disease virusesin cattle in Reunion Island. Veterinary Microbiology, 2011, 155, pp.191-197. 10.1016/j.vetmic.2011.09.006 . hal-01191083

\section{HAL Id: hal-01191083 \\ https://hal.science/hal-01191083}

Submitted on 1 Sep 2015

HAL is a multi-disciplinary open access archive for the deposit and dissemination of scientific research documents, whether they are published or not. The documents may come from teaching and research institutions in France or abroad, or from public or private research centers.
L'archive ouverte pluridisciplinaire $\mathbf{H A L}$, est destinée au dépôt et à la diffusion de documents scientifiques de niveau recherche, publiés ou non, émanant des établissements d'enseignement et de recherche français ou étrangers, des laboratoires publics ou privés. 


\title{
Co-circulation of bluetongue and epizootic haemorrhagic disease viruses in cattle in Reunion Island
}

\author{
Corinne Sailleau $^{\mathrm{a}, *}$, Gina Zanella ${ }^{\mathrm{a}}$, Emmanuel Breard ${ }^{\mathrm{a}}$, Cyril Viarouge $^{\mathrm{a}}$, Alexandra Desprat $^{\mathrm{a}}$, \\ Damien Vitour ${ }^{a}$, Micheline Adam ${ }^{a}$, Laurent Lasne ${ }^{b}$, Arnaud Martrenchar ${ }^{c}$, \\ Labib Bakkali-Kassimi ${ }^{\mathrm{a}}$, Laura Costes ${ }^{\mathrm{b}}$, Stéphan Zientara ${ }^{\mathrm{a}}$ \\ ${ }^{a}$ French Agency for Food, Environmental and Occupational Health and Safety (ANSES), 23 Avenue du Général de Gaulle 94706 Maisons-Alfort Cedex, France \\ ${ }^{\mathrm{b}}$ Directorate for Food, Agriculture and Forestry - Parc de la Providence 97488 Saint Denis Cedex, France \\ ${ }^{\mathrm{c}}$ General Delegation of French Overseas Regions, 27, rue Oudinot, 75007 Paris, France
}

\section{A R T I C L E I N F O}

\section{Article history:}

Received 3 May 2011

Received in revised form 29 August 2011

Accepted 5 September 2011

\section{Keywords:}

Orbivirus

Epizootic haemorrhagic disease in deer

Bluetongue

Molecular diagnosis

\begin{abstract}
A B S T R A C T
Bluetongue virus (BTV) and epizootic haemorrhagic disease virus (EHDV) in deer have already been isolated in Reunion Island and have caused more or less severe clinical signs in cattle (EHDV) or in sheep (BTV), as observed in 2003. In January 2009, cattle in Reunion Island showed clinical signs suggesting infection by one or the other of these arboviral diseases. A study was set up to determine the etiology of the disease. Analysis by reverse transcriptase-polymerase chain reaction (RT-PCR) performed on blood samples from 116 cattle from different districts of the island detected the presence of the EHDV genome in 106 samples and, in 5 of them, the simultaneous occurrence of BTV and EHDV. One strain of EHDV (7 isolates) and one of BTV were isolated in embryonated eggs and a BHK-21 cell culture. Group and subgroup primer-pairs were designed on the segment 2 sequences available in GenBank to identify and type the EHDV strains.

Phylogenetic analysis of the genomic segment 2 (encoding the VP2 serotype-specific protein) of the isolates confirmed the serotypes of these two orbiviruses as BTV-2 and EHDV-6 and allowed them to be compared with previously isolated strains.
\end{abstract}

(c) 2011 Elsevier B.V. All rights reserved.

\section{Introduction}

Bluetongue virus (BTV) and epizootic haemorrhagic disease virus (EHDV) belong to the family Reoviridae and the genus Orbivirus (Verwoerd and Erasmus, 2004; Maclachlan and Osburn, 2004). These two viruses have structural, antigenic and molecular similarities. Both viruses are transmitted to their host range (ruminants) by the bites of Culicoides midges. Serological and molecular techniques for the laboratory diagnosis of these two diseases are very similar.

Both viruses have seven different structural proteins (VP1 to VP7) divided into two capsids (Roy, 2005). The

\footnotetext{
* Corresponding author. Tel.: +33 149772707; fax: +33 143689762.

E-mail address: corinne.sailleau@anses.fr (C. Sailleau).
}

outer capsid consists of VP2 and VP5. The VP2 protein, the major constituent of the outer capsid, is exposed on the surface of the virus particle and determines the serotypespecific antigen. Twenty-four BTV serotypes and 7 EHDV serotypes have been identified (Anthony et al., 2009). The specific antigens of each serotype induce the production of serotype-specific neutralising antibodies. Segment 2, which encodes VP2, is favoured for conducting studies of genetic variability between different serotypes.

EHDV primarily infects wild ruminants such as deer, which develop the most severe clinical signs. Several strains - including strains of EHDV serotype 2 (Ibaraki strain), 6 and 7 - can also cause a severe disease in cattle; clinical signs observed are similar to those caused by the European strain of BTV-8. EHD is endemic in the United States and Canada, where it causes clinical signs exclusively in certain species of deer. In Australia, Southeast 
Asia, sub-Saharan Africa and, since 2006, in the Maghreb countries (serotype 6) and the Arabian Peninsula (serotype 7 ), it occurs in outbreaks and causes seasonal clinical signs in cattle.

In January 2009, cattle in Reunion Island showed clinical signs of hyperthermia, anorexia, congestion and petechia of the oral mucosa, prostration and nasal discharge. Some animals had a severe dyspnea, facial oedema and lameness. The morbidity rate was $0.8 \%$ and the case fatality rate was estimated at $11 \%$. This clinical pattern could be attributed to BTV or EHDV.

In this article, we present a study, which was set up in February 2009 to determine the etiology of this disease and to quantify the clinical signs displayed by cattle in 2009 in Reunion Island. The laboratory diagnostic techniques developed and used to identify viruses responsible for the observed pathology are described.

\section{Materials and methods}

\subsection{Clinical studies}

Private veterinarians participating in the study were asked to take blood samples from at least 100 cattle showing EHD clinical signs. They also had to fill out a detailed questionnaire on clinical signs and lesions observed.

\subsection{Blood samples}

EDTA blood samples were collected from cattle displaying clinical signs, for viral isolation and RT-PCR assays.

\subsection{Nucleic acid sample preparation, $R T-P C R$ reactions and sequencing}

Total RNA was extracted from $100 \mu \mathrm{l}$ of blood samples using the QIAcube robot (QIAGEN) and the QIAamp Viral kit (QIAGEN; reference: 52906) according to the manufacturer's instructions. Finally, the RNAs were eluted with $50 \mu \mathrm{l}$ of ultrapure water and used in specific EHDV and BTV RT-PCR.

\subsubsection{BTV group-specific RT-PCR}

Reverse transcription (RT) and amplification were performed using a commercial real-time RT-PCR kit (ADI-352, AES) according to the manufacturer's instructions. This kit allows all 24 serotypes to be detected (by amplifying BTV segment 10 which encodes NS3).

\subsubsection{EHDV group-specific RT-PCR}

Group-specific primer-pairs (EHDVF617 cgc aca Rga Kac Rccaca; EHDVR1070 ccc tca cat/c ata ggc gtt tt) derived from the nucleotide sequence data of genome segment 7 of EHDV available in GenBank were used in conventional RTPCR using the one-step RT-PCR Kit (Qiagen, Courtaboeuf, France). Briefly, $2.5 \mu$ l of denatured RNA were added to a mixture containing $15.2 \mu \mathrm{l}$ of RNase-free water, $5 \mu \mathrm{l}$ of $5 \mathrm{X}$ QIAGEN one-step RT-PCR buffer, $1 \mu$ l of dNTP mix ( $400 \mu \mathrm{M}$ of each dNTP), $0.6 \mu \mathrm{M}$ of each primer, $1 \mu \mathrm{l}$ of QIAGEN onestep RT-PCR Enzyme. The amplification was carried out according to the following cycling parameters: $50{ }^{\circ} \mathrm{C}$ for $30 \mathrm{~min}, 95^{\circ} \mathrm{C}$ for $15 \mathrm{~min}$, followed by 40 cycles of $1 \mathrm{~min}$ at $94^{\circ} \mathrm{C}, 1 \mathrm{~min}$ at $56^{\circ} \mathrm{C}$ and $1 \mathrm{~min}$ at $72^{\circ} \mathrm{C}$. A quota of ten microlitres of each RT-PCR product was analysed by electrophoresis on a $2 \%$ agarose gel.

\subsubsection{EHDV subgroup-specific primers}

The alignment (Megalign) of the segment 2 nucleotide sequences available in GenBank shows 4 clusters (Fig. 1). Sequence data were used to design one primer-pair for each cluster (Table 1) allowing the amplification of each serotype for each group. These primers were selected in a conserved region of each group. These four primer-pairs were used in RT-PCR assays using the same protocol as described above. In order to determine the serotype, each amplification product was sequenced.

\subsubsection{Sequencing of amplified products}

2.3.4.1. EHDV Sequencing. Amplified RT-PCR products were sequenced directly, in both directions, using the primerpairs (Table 1) (Cogenics). Sequences were assembled by SeqMan (DNAstar programs, Lasergene) and compared (Blastn 2.2.23) to the homologous sequences available in

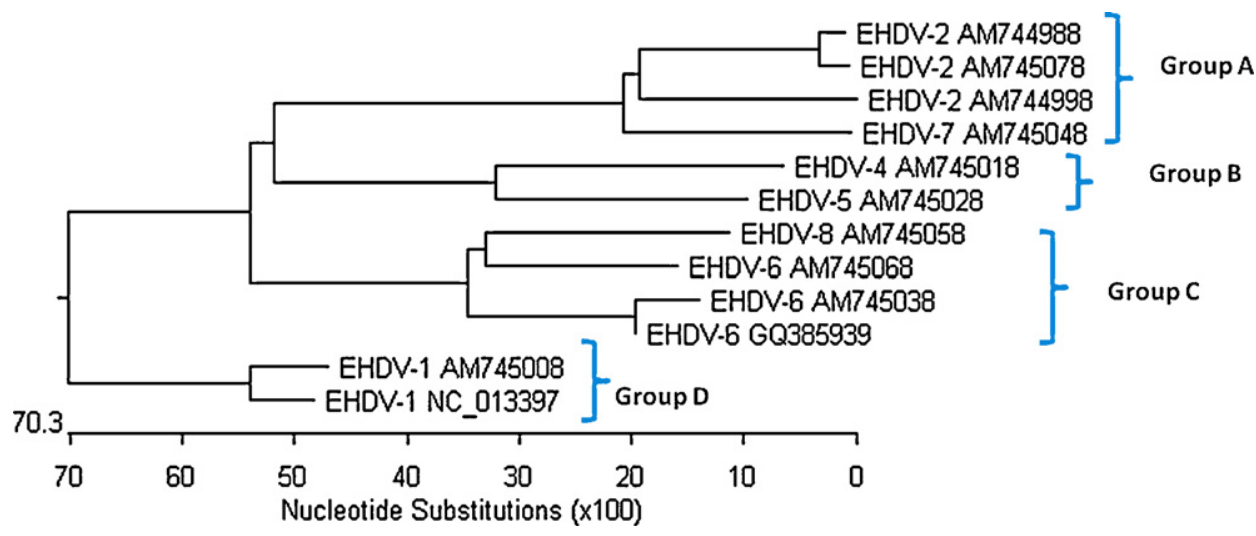

Fig. 1. Phylogenetic tree of full-length segment 2 sequences showing relationships between EHDV serotypes (GenBank). The serotypes of EHDV are associated in 4 Clusters (A, B, C and D). 
Table 1

EHDV subgroup-specific primers.

\begin{tabular}{|c|c|c|c|c|c|c|c|c|}
\hline & $\begin{array}{l}\text { Forward } \\
\text { primer }\end{array}$ & Sequence $\left(5-3^{\prime}\right)$ & Localisation & $\begin{array}{l}\text { Reverse } \\
\text { primer }\end{array}$ & Sequence $\left(5-3^{\prime}\right)$ & Localisation & $\begin{array}{l}\text { Amplified } \\
\text { product size }\end{array}$ & $\begin{array}{l}\text { Serotype } \\
\text { amplified }\end{array}$ \\
\hline Group A & EHDAF & ATACGCCGATATGACTGG & $255-272$ & EHDAR & GATGATAATTCCTTATGTTTCG & $1041-1020$ & 786 & $\begin{array}{l}\text { EHDV2 } \\
\text { EHDV7 }\end{array}$ \\
\hline Group B & EHDBF & ATTATGAGATTTCATTATGGG & $2479-2500$ & EHDBR & AGCTTCAGTCACGAAGC & $3001-2985$ & 522 & $\begin{array}{l}\text { EHDV4 } \\
\text { EHDV5 }\end{array}$ \\
\hline Group C & EHDCF & GTTAAATTATTCCAGGATGG & $1-20$ & EHDCR & TTCCATATTCTGGTTTAATCC & $391-372$ & 391 & $\begin{array}{l}\text { EHDV6 } \\
\text { EHDV8 }\end{array}$ \\
\hline Group D & EHDDF & GTTAAATTGTGTCAGGATGG & $1-20$ & EHDDR & CCGTCTACCCATTTCATCC & $820-801$ & 820 & EHDV1 \\
\hline
\end{tabular}

GenBank. Based on the segment 2 nucleotide sequences of identified serotypes available in GenBank, primers were designed to sequence the full length segment 2 nucleotide sequences. Sequence alignments were performed using MegAlign-Clustal V method (DNAstar software).

2.3.4.2. BTV sequencing. Based on the segment 2 nucleotide sequences of BTV-2 available in GenBank, primers were designed to sequence the segment 2 of the isolated strain.

\subsection{Virus isolation}

Individual groups of three embryonated chicken eggs (ECE) were each inoculated intravenously with $0.1-0.2 \mathrm{ml}$ of a $10^{-1}$ dilution of washed and lysed blood (Clavijo et al., 2000). The eggs were incubated for 5 days at $35^{\circ} \mathrm{C}$ and examined daily using a cold candling lamp. The embryos that died within $24 \mathrm{~h}$ were discarded. The embryos that died between days 2 and 5 were removed and homogenised in a pestle with sterile sand and Eagle's MEM, supplemented with $100 \mu \mathrm{g} / \mathrm{ml}$ streptomycin and $100 \mathrm{UI} /$ $\mathrm{ml}$ penicillin, using a mortar to give a final $10 \%$ suspension. The tissue homogenates were clarified by centrifugation at $2000 \times \mathrm{g}$ for $10 \mathrm{~min}$ at $4{ }^{\circ} \mathrm{C}$ and inoculated into BHK-21 cells. Inoculated flasks were incubated at $37^{\circ} \mathrm{C}$ and examined under a microscope every day for 7 days to check for the appearance of cytopathic effects (CPE).

\subsubsection{Virus neutralisation test}

Virus neutralisation tests (VNT) were carried out using methods similar to those described in the OIE Manual of Standards for diagnostic tests and vaccines (OIE, 2009). All assays were carried out in microtitre plates. Constant amounts of each BTV type-specific antiserum (50 $\mu \mathrm{l} /$ well) were added to a tenfold dilution series of each virus sample (50 $\mu \mathrm{l} /$ well) and the serum-virus mixtures incubated for $1 \mathrm{~h}$ at $37^{\circ} \mathrm{C}$. BHK-21 cells $(100 \mu \mathrm{l} /$ well $)$, diluted in Eagle's MEM, supplemented with $5 \%$ of foetal calf serum, $100 \mu \mathrm{g} /$ $\mathrm{ml}$ streptomycin and $100 \mathrm{IU} / \mathrm{ml}$ penicillin, were then added at a concentration of $10^{5}$ cells $/ \mathrm{ml}$. Microtitre plates were sealed, incubated at $37^{\circ} \mathrm{C}$ for 7 days and examined under a microscope each day to check for CPE. The BTV typespecific antiserum that reduced the virus titre by at least two $\log _{10}$ compared with the virus control in the absence of any antiserum designated the virus serotype.

\section{Results}

\subsection{Clinical signs and epidemiological data}

The age of affected animals ranged from 6 months to 10 years. All were of European breeds (Holstein, Limousine, Blonde d'Aquitaine and Aubrac) and cross-bred cattle. Questionnaires on clinical signs were filled out for 67 cattle, all of which were EHDV positive. Fig. 2 summarises the percentage of clinical signs associated with EHDV

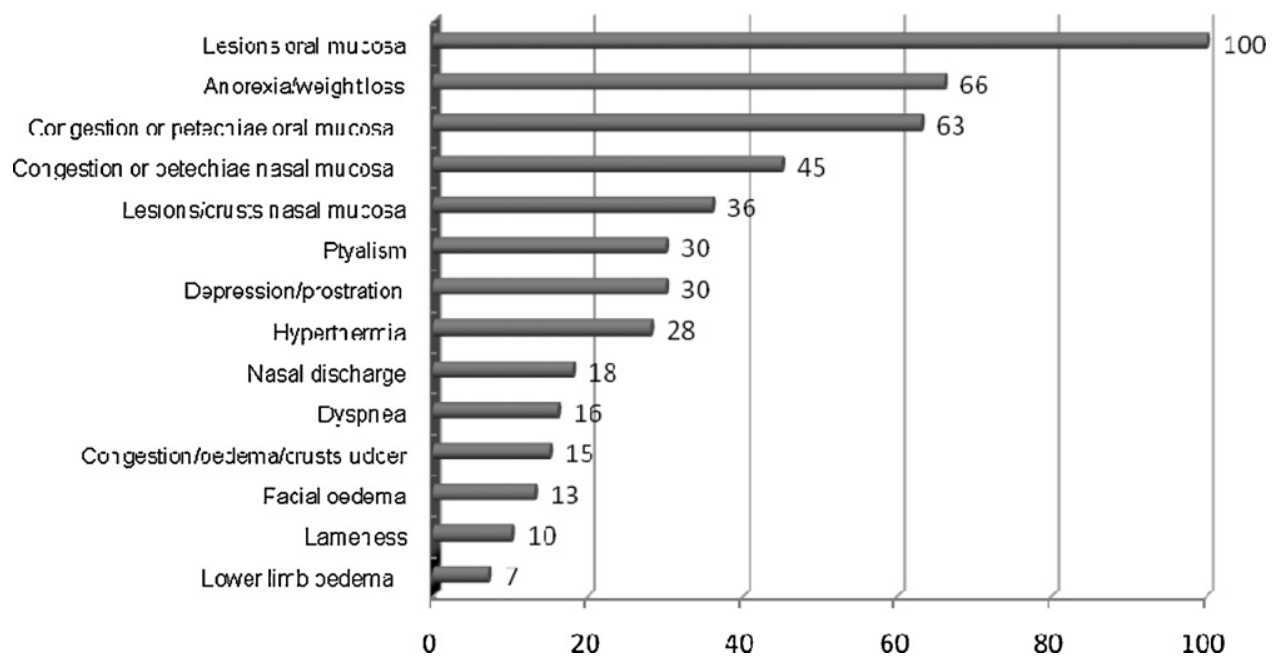

Fig. 2. Percentage of EHDV clinical signs found in 67 cattle in Reunion Island during the 2009 epizootic. 
Table 2

Distribution of EHDV and BTV RT-PCR-positive cattle.

\begin{tabular}{lccl}
\hline District & $\begin{array}{l}\text { Number of } \\
\text { sampled } \\
\text { cattle }\end{array}$ & $\begin{array}{l}\text { Number of } \\
\text { EHDV } \\
\text { RT-PCR + cattle }\end{array}$ & $\begin{array}{l}\text { Number of EHDV } \\
\text { RT-PCR + and BTV } \\
\text { RT-PCR + cattle }\end{array}$ \\
\hline Le Tampon & 73 & 68 & 0 \\
L'Entre-Deux & 3 & 3 & 0 \\
Les Trois-Bassins & 3 & 3 & 0 \\
\hline Saint-Joseph & 2 & 2 & 0 \\
Saint-Leu & 30 & 26 & 5 \\
Saint-Louis & 1 & 0 & 0 \\
Saint-Pierre & 4 & 4 & 0 \\
Total & 116 & 106 & 5 \\
\hline
\end{tabular}

observed in these animals. The most common clinical signs were: anorexia, weight loss, ptyalism, depression and hyperthermia. Congestion, petechiae and lesions (erosions or ulcers) in oral and nasal mucosae were the most frequent lesions observed. A reduction in the milk yield was reported in 7 of the 20 dairy cows (Holstein) included in the sample. The five beef cows that were co-infected with EHDV and BTV showed congestion, petechiae or lesions in oral and nasal mucosae.

\section{2. $R T-P C R$ analysis}

A total of 116 cattle, belonging to 57 farms spread across 7 districts of the island, were blood sampled. Ninety one percent $(n=106)$ were EHDV positive and $4 \%(n=5)$ were both BTV and EHDV positive (Table 2). The latter five animals were from the same breed (Limousine).

\subsection{Viral isolation}

Eleven blood samples caused haemorrhagic lesions on embryos and CPE on BHK-21 after the first passage. On the basis of the PCR results using EHDV- and BTV-specific RTPCR, 7 strains were identified as EHDV, one strain was identified as BTV and co-infection with EHDV and BTV strains was found in three samples.

\subsection{Virus serotyping and sequence analysis}

\subsubsection{BTV strain}

On the basis of the VNT results, the BTV strain was identified as BTV-2. This result was confirmed by sequence analysis of segment 2 (GenBank accession number HQ222824). The comparison with corresponding sequences available in GenBank showed identity from $79.5 \%$ to $87.9 \%$ (nucleotides) and from $91 \%$ to $96.3 \%$ (amino acids) (Table 3).

\subsubsection{EHDV strains}

RT-PCR using four primer-pairs (Table 1 ) performed on total RNA extracted from $100 \mu$ l of EHDV infected cell culture or directly from EHDV infected blood allowed the amplification of 7 products only with the primer-pair (group C). The sequence determination and alignment

Table 3

Nucleotide and amino acid identity (\%) of genome segment 2 and VP2 of BTV-2 Reunion compared with the cognate region in other BTV-2 strains.

\begin{tabular}{|c|c|c|c|c|c|c|}
\hline & \multicolumn{6}{|l|}{ Nucleotides } \\
\hline & BTV-2 Reunion & BTV-2 Martinique & BTV-2 France & BTV-2 Italy & BTV-2 USA & BTV-2 SA \\
\hline $\begin{array}{l}\text { BTV-2 Reunion } \\
\text { (HQ222824) }\end{array}$ & 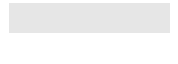 & 79.5 & 87.4 & 87.2 & 87.9 & 87.8 \\
\hline $\begin{array}{l}\text { BTV-2 Martinique } \\
\text { (HQ222820) }\end{array}$ & 91 & & 79.6 & 79.4 & 80.4 & 80.5 \\
\hline $\begin{array}{l}\text { BTV-2 France } \\
\text { (AF356601) }\end{array}$ & 96.3 & 90.9 & & 99.7 & 96.3 & 96.5 \\
\hline $\begin{array}{l}\text { BTV-2 Italy } \\
\text { (AM773698) }\end{array}$ & 96 & 90.6 & 99.6 & & 96 & 96.2 \\
\hline $\begin{array}{l}\text { BTV-2 USA } \\
\text { (AY855265) }\end{array}$ & 96.3 & 96.3 & 98.2 & 97.2 & & 99.5 \\
\hline $\begin{array}{l}\text { BTV-2 SA } \\
(\text { AY855265) }\end{array}$ & 96.2 & 90.7 & 98.3 & 98 & 99.8 & \\
\hline & Amino acids & & & & & \\
\hline
\end{tabular}

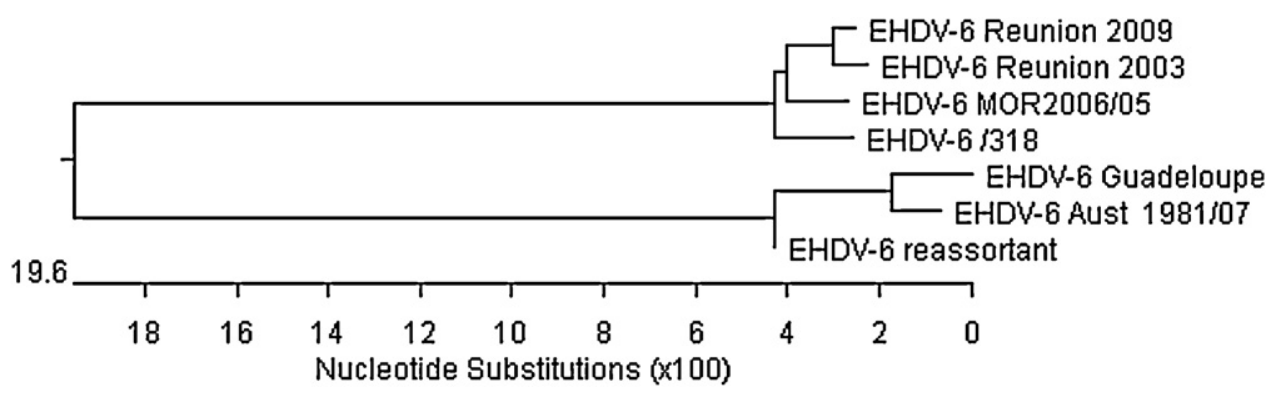

Fig. 3. Phylogenetic tree of full-length segment 2 sequences showing relationships between EHDV-6 strains (clustal analysis). 
Table 4

Nucleotide and amino acid identity (\%) of genome segment 2 and VP2 of EHDV Reunion compared with the cognate region in other EHDV strains (GenBank accession number in brackets).

\begin{tabular}{|c|c|c|c|c|c|c|c|}
\hline & \multicolumn{7}{|l|}{ Nucleotides } \\
\hline & $\begin{array}{l}\text { EHDV-6 } \\
\text { Reunion } 2009\end{array}$ & $\begin{array}{l}\text { EHDV-6 } \\
\text { Reunion } 2003\end{array}$ & $\begin{array}{l}\text { EHDV-6 } \\
\text { MOR 2006/05 }\end{array}$ & EHDV-6 318 & $\begin{array}{l}\text { EHDV-6 } \\
\text { AUS1981/07 }\end{array}$ & $\begin{array}{l}\text { EHDV-6 } \\
\text { Guadeloupe }\end{array}$ & $\begin{array}{l}\text { EHDV }-6^{\mathrm{a}} \\
\text { reassortant }\end{array}$ \\
\hline $\begin{array}{l}\text { EHDV-6 Reunion } 2009 \\
\text { (HQ848379) }\end{array}$ & & 98.8 & 97.1 & 96.5 & 68.4 & 68.2 & 71.2 \\
\hline $\begin{array}{l}\text { EHDV-6 Reunion } 2003 \\
\text { (HQ222817) }\end{array}$ & 98.9 & & 97.1 & 96.5 & 67.8 & 67.6 & 70.6 \\
\hline $\begin{array}{l}\text { EHDV-6 MOR 2006/05 } \\
\text { (HM156730) }\end{array}$ & 98.9 & 98.1 & & 96.5 & 67.8 & 67.6 & 70.6 \\
\hline $\begin{array}{l}\text { EHDV-6 /318 } \\
(\text { AM745068) }\end{array}$ & 98.9 & 98 & 98.8 & & 68.1 & 68.1 & 71 \\
\hline $\begin{array}{l}\text { EHDV-6 AUS1981/07 } \\
\text { (AM745038) }\end{array}$ & 77 & 76 & 77 & 76.7 & & 97.2 & 98.1 \\
\hline $\begin{array}{l}\text { EHDV-6 Guadeloupe } \\
\text { (HQ 848380) }\end{array}$ & 76 & 76.1 & 76.4 & 76.2 & 96.9 & & 96.8 \\
\hline $\begin{array}{l}\text { EHDV-6 reassortant } \\
\text { (GO285939) }\end{array}$ & 80.8 & 79.9 & 80.3 & 80.8 & 97.9 & 95.6 & \\
\hline
\end{tabular}

Amino acid

a Partial sequence (1014 nucleotides and 338 aa).

(Blastn) of $391 \mathrm{pb}$ amplified products indicated identity of 97\% to EHDV-6/strain 318 (AM775068). Sequences of each isolate were identical to each other.

The full length seg-2 sequence of one isolate was determined (HQ848379). Clustal alignment with the cognate gene (EHDV-6) present in GenBank indicated between $68.2 \%$ and $98.8 \%$ identity (76\% and $98.9 \%$ amino acid identity) (Table 4 and Fig. 3).

\section{Discussion}

The number of clinical cases during the 2009 EHDV epizootic was estimated to be at least 270 in Reunion Island. Only 116 were analysed in our study. Of the 116 animals tested, 91\% were RT-PCR EHDV positive and 4\% were both RT-PCR EHDV and BTV positive. These results demonstrate the involvement of EHDV in observed "BTVlike" clinical signs. It is very likely that other animals on the island were co-infected with EHDV and BTV. The presence of these two orbiviruses has been reported several times in Reunion Island. From 1974 to 1979, serological data indicated the presence of BTV on the island (personal data). In January 2003, EHDV caused a severe epizootic in cattle (Breard et al., 2004) and in the same year an outbreak of bluetongue was described in a flock of Merino sheep (Breard et al., 2005). In 2008, a serological survey of over a hundred cattle from Reunion Island conducted by the Onderstepoort Veterinary Institut (South Africa) showed that $88 \%$ of the animals were seropositive, as determined by BTV-ELISA. In SNT assays, high titres $(\geq 1 / 80)$ were obtained against BTV 2, 3, 9, 10, 12, 13, 14, 15 and 16, and lower but significant titres $(1 / 20 \leq$ titre $\geq 1 / 40)$ against BTV 1, 5, 8, 20, 21, 23 and 22 (personal data). These results suggest that more than a dozen serotypes have circulated or circulate in recent years on the island.

EHDV clinical signs in cattle, involving EHDV-2, 6 and 7, had previously been reported in Japan (1959/60 and 1997), Reunion Island (2003), Morocco (2006), Israel (2006) and Turkey (2007) (Inaba, 1975; Breard et al., 2004; OIE, 2006;
Yadin et al., 2008; Temizel et al., 2009) and were very similar to those observed and quantified in our study.

Since, to our knowledge, the BTV-2 serotype has never caused clinical signs in cattle, it is likely that the lesions displayed by the EHDV and BTV2 co-infected cows found in our study were due to EHDV. Moreover, the serological findings indicate that BTV2 is circulating silently on the island. Unfortunately, questionnaires were not filled out for ten EHDV-negative animals showing clinical signs that may have allowed us to propose a differential diagnosis.

The analysis of genome segment 2 sequence of the EHDV strain performed in this study showed a high homology in nucleotides and amino acids (98.8\% and $98.9 \%$, respectively) with the homologous genes and proteins from the strain that caused an epizootic on the Island in 2003 (Breard et al., 2004). These data suggest that the same strain has been circulating on the Island for 7 years. In the period of time between the two epizootics, no clinical signs were reported. We can assume that sporadic cases have occurred but have gone unnoticed. Because of the lack of serological data from 2003 to 2009, it is impossible to determine whether any change has occurred in the EHDV seroprevalence rate.

Sequence comparison with other EHDV-6 strains showed a high identity to the "western virus" (Anthony et al., 2009) EHDV-6 strain 318 (nucleotides: 96.5\%, amino acids: $98.9 \%$ ) and a lower identity (68.2\% to $71.2 \%$ in nucleotides and $76 \%$ to $80.8 \%$ in amino acids) to "eastern" viruses (Maan et al., 2010) EHDV-6 AUS1981/07, EHDV-6 (reassortant) isolated in USA in 2006, and EHDV-6 detected in Guadeloupe in 2010.

These sequence data indicate that the EHDV strain circulating in Reunion Island is closely related to the EHDV-6 that circulated in the Mediterranean Basin in 2006-2007 (nucleotide and amino acid identity of $97.1 \%$ and 98.9\%, respectively, to isolate MOR2006/05 Table 4). Further sequence analyses of the whole genome are needed to determine if the two strains have the same origin. 
In this study we also described the presence of one BTV2 isolate. Despite serological data in 2009 showing the recent circulation of BTV-2 on the island (personal data), this serotype has never been isolated. In 2003, BTV-3 was responsible for an outbreak in sheep (Breard et al., 2005). The comparison of nucleotide sequences of segment 2 of the BTV-2 strain with the homologous sequences present in GenBank shows rates of divergence at least equal to $12 \%$ or greater than those usually observed. This result does not allow us to put forward a hypothesis concerning the origin of the BTV-2. The isolation of this virus, even if it is not responsible for the clinical signs observed, confirms the enzootic nature of the BTV in Reunion Island.

When this study was conducted, no serological or molecular tools were available for EHDV typing. Only a few group-specific gel-based RT-PCR assays (Aradaib et al., 1995,2003 ) had been developed and no reference serum was available for the VNT. In this study, we describe a new group-specific gel-based RT-PCR for detecting all EHDV serotypes and a method to easily identify the EHDV serotypes. For this purpose, we selected sub-group primers, which allowed the amplification of serotypes in each cluster (Table 1). These RT-PCRs, supplemented by nucleotide sequencing, were successfully used to identify the serotypes of EHDV directly isolated from blood or infected culture cells. Recently, new group-(real time) or type-(conventional) specific RT-PCR assays have been developed (commercial assay - LSI) (Wilson et al., 2009; Clavijo et al., 2010; Maan et al., 2010) which allow rapid and sensitive detection and identification of recent isolates from the Mediterranean region and North America. Our method for identifying EHDV serotypes (PCR + sequencing) uses primers selected in more highly conserved genome regions of segment 2 than those described in Maan et al. (2010). The use of a RT-PCR that is less selective (amplification of more than one serotype) can be an advantage in the case of mutations on the segment 2 which could cause the type-specific RT-PCR to fail. Moreover, the sequence data allow both formal identification of the serotype and provide useful information about the strain. Phylogenetic comparison of segment 2 sequences helps to understand the epidemiology of the virus.

As with the EHDV-6 reported in the Mediterranean Basin, the EHDV-6 strain isolated in Reunion Island was shown to be linked to severe clinical signs in cattle. This had not been described with the EHDV-6 reported in Australia during 1977-1982 (Parsonson and Snowdon, 1985) or with the new EHDV-6/EHDV-2 reassortant isolated from white - tailed deer (Allison et al., 2010).

How and when EHDV was introduced onto the island remains unknown. As with BTV, it is likely that it was introduced by infected animals from Africa, Madagascar or Australia over the course of many years. Since the beginning of the 1990s, introduction of animals from these countries has stopped and imports were all from France (free of EHDV). A wind-borne introduction of infected midges is unlikely, given the considerable distance from Africa - Reunion island lying $800 \mathrm{~km}$ to the east of Madagascar - and the prevailing southeasterly trade winds. We can therefore assume that the virus remained present on the island. The possible role of Sika deer, reared on the island, in the EHD epidemiology remains to be determined.

The general consensus is that, for both BTV and EHDV, the serotype alone does not determine the virulence of a strain (Maclachlan et al., 2009), but rather that other factors, such as breed, play an important role. In our study, however, we observe no link between the factors of either age or breed and the presence or absence of clinical signs.

Finally, the simultaneous presence of several strains of orbivirus (EHDV and/or more than one serotype of BTV) reveals that co-infection of animals (BTV/BTV or BTV/ EHDV), as observed during this clinical episode (5 cattle infected with both viruses), is possible. Furthermore, this could favour reassortment mechanisms that may lead to the emergence of new virulent strains.

\section{Acknowledgments}

We thank the RFSA (Réseau Français pour la Santé Animale) and Epizone (FP6-2004-food-3-A) for their financial support.

\section{References}

Allison, A.B., Goekjian, V.H., Potgieter, A.C., Wilson, W.C., Johnson, D.J., Mertens, P.P.C., Stallknecht, D.E., 2010. Detection of a novel reassortant epizootic hemorrhagic disease virus (EHDV) in the USA containing RNA segments derived from both exotic (EHDV-6) and endemic (EHDV-2) serotypes. J. Gen. Virol. 91 (Pt 2), 430-439.

Anthony, S.J., Maan, N., Maan, S., Sutton, G., Attoui, H., Mertens, P.P., 2009 Genetic and phylogenetic analysis of the non-structural proteins NS1, NS2 and NS3 of epizootic haemorrhagic disease virus (EHDV). Virus Res. 145 (2), 211-219.

Aradaib, I.E., Mcbride, J.W., Wilson, W.C., Osburn, B.I., 1995. Development of polymerase chain reaction for specific identification of epizootic hemorrhagic disease virus serotype 1. Arch. Virol. 140 (12), 2273-2281.

Aradaib, I.E., Mohamed, M.E.H., Abdalla, M.A., Karrar, A.E., Majid, A.A., Omer, R.A., Elamin, S.M.M., Salih, M.M., Idress, S.H., 2003. Simultaneous detection and identification of epizootic hemorrhagic disease virus serotype 1 and 2 using a multiplex RT PCR. J. Anim. Vet. Adv. 2, 585-589.

Breard, E., Sailleau, C., Hamblin, C., Graham, S.D., Gourreau, J.M., Zientara, S., 2004. Outbreak of epizootic haemorrhagic disease on the island of Reunion. Vet. Rec. 155, 422-423.

Breard, E., Sailleau, C., Hamblin, C., Zientara, S., 2005. Bluetongue virus in the French Island of Reunion. Vet. Microbiol. 106, 157-165.

Clavijo, A., Heckert, R.A., Dulac, G.C., Afshar, A., 2000. Isolation and identification of Bluetongue virus. J. Virol. Methods 87, 13-23.

Clavijo, A., Sun, F., Lester, T., Jasperson, D.C., Wilson, W.C., 2010. An improved real-time polymerase chain reaction for the simultaneous detection of all serotypes of epizootic hemorrhagic disease virus. J. Vet. Diagn. Invest. 22 (4), 588-593.

Inaba, U., 1975. Ibaraki disease and its relationship to bluetongue. Aust. Vet. J. 51 (4), 178-185.

Maan, N.S., Maan, S., Nomikou, K., Johnson, D.J., El Harrak, M., Madani, H. Yadin, H., Incoglu, S., Yesilbag, K., Allison, A.B., Stallknecht, D.E. Batten, C., Anthony, S.J., Mertens, P.P.C., 2010. RT-PCR assays for seven serotypes of epizootic haemorrhagic disease virus and their use to type strains from the Mediterranean region and North America. PLoS One 17, 5 (9).

Maclachlan, N.J., Osburn, B.I., 2004. Epizootic Haemorrhagic Disease of Deer. Infectious Diseases of Livestock, vol. 2. , pp. 1227-1230.

Maclachlan, N.J., Drew, C.P., Darpel, K.E., Worwa, G., 2009. The pathology and pathogenesis of bluetongue. J. Comp. Pathol. 141, 1-16.

OIE, 2009. Manual of Diagnostic Tests and Vaccines for Terrestrial Animals, Terrestrial Manual, 6th Edition, 1 and 2, Chapter 2.1.3.

OIE Disease information, 2006., vol 19, 2 Nov. 44; 51.

Parsonson, I.M., Snowdon, W.A., 1985. Bluetongue, epizootic haemorrhagic disease of deer and related viruses: current situation in Australia. Prog. Clin. Biol. Res. 178, 27-35. 
Roy, P., 2005. Bluetongue virus proteins and particles and their role in virus entry, assembly, and release. Adv. Virus Res. 64, 69-123.

Temizel, E.M., Yesilbag, K., Batten, C., Senturk, S., Maan, N.S., Mertens, P.P.C., Batmaz, H., 2009. Epizootic hemorrhagic disease in cattle, Western Turkey. Emerg. Infect. Dis. 15 (2), 317-319.

Verwoerd, D.W., Erasmus, B.J., 2004. Bluetongue. In: Coetzer, J.A.W., Tustin, R.C. (Eds.), Infectious Diseases of Livestock. 2nd ed. Oxford University Press Southern Africa, Cape Town, pp. 1201-1220.
Wilson, W.C., O'Hearn, E.S., Tellgren-Roth, C., Stallknecht, D.E., Mead, D.G., Mecham, J.O., 2009. Detection of all eight serotypes of epizootic hemorrhagic disease virus by real-time reverse transcription polymerase chain reaction. J. Vet. Diagn. Invest. 21, 220-225.

Yadin, H., Brenner, J., Bumbrov, V., Oved, Z., Stram, Y., Klement, E., Perl, S. Anthony, S., Maan, S., Batten, C., Mertens, P.P., 2008. Epizootic haemorrhagic disease virus type 7 infection in cattle in Israel. Vet. Rec. $162,53-56$. 